\title{
Internal logistics as a control and modeling tool in the processes of organizations
}

\section{La logística interna como herramienta de control y modelado en los procesos de las organizaciones}

CHACÓN-OLIVARES, Maria del Carmen ${ }^{1} \dagger^{*}$, RUELAS-SANTOYO, Edgar Augusto $^{2}$, RICOCHAGOLLÁN, Mariana ${ }^{3}$ and LÓPEZ-OLIVAREZ, Jaqueline Viridiana ${ }^{3}$

Instituto Tecnológico superior de Irapuato. ${ }^{1}$ Ingeniería en Logística, ${ }^{2}$ Ingeniería Industrial, ${ }^{3}$ Ingeniería en Sistemas Computacionales Carretera Irapuato - Silao km 12.5 Colonia El Copal. Irapuato, Guanajuato, México. 36820

ID $1^{\text {st }}$ Author: Maria Del Carmen, Chacón-Olivares / ORC ID: 0000-0002-3897-0235, Researcher ID Thomson: S-48062018, CVU CONACYT ID: 891518

ID $1^{\text {st }}$ Coauthor: Edgar Augusto, Ruelas-Santoyo / ORC ID: 0000-0003-0515-7667

ID $2^{\text {nd }}$ Coauthor: Mariana, Rico-Chagollán / Researcher ID Thomson: S-7659-2018, CVU CONACYT ID: 691659

ID $3^{\text {rd }}$ Coauthor: Jaqueline Viridiana, López-Olivarez

DOI: $10.35429 / J M P C .2019 .16 .5 .8 .14$

Received June 10, 2019; Accepted December 30, 2019

\begin{abstract}
Nowadays, companies face scale or production volume margins accelerated to respond and meet the needs of international markets, logistics and supply chain is then a key strategy to add value and competitive advantage. Through an investigation of observation and data collection, it was determined that there is no capacity for response and control before the increase in production, it is then that the objective of this work is to establish an order in the internal flow of materials, by medium of the implementation of an internal logistics process in a company that produces aluminum parts. For which a model was created that considered variables such as: the determination of spaces, control of documented information, creation of traceability and training record formats, which produced the following results: improvement in internal flows by $80 \%$, a correct traceability in the handling of the materials that reduced the times by $50 \%$, in addition to the incorporation of programs of administrative platforms. Therefore, the appropriate elements that make up the adoption of the strategy and its measurement in performance indices were determined.
\end{abstract}

Internal logistics, Traceability, Internal flow

\begin{abstract}
Resumen
Hoy en día las empresas enfrentan escala o márgenes de volumen de producción acelerados para responder y cubrir las necesidades de los mercados internacionales, la logística y cadena de suministro es entonces una estrategia primordial para agregar valor y ventaja competitiva. A través de una investigación de observación y toma de datos, se determinó que no existe capacidad de respuesta y control ante el incremento en la producción, es entonces que el objetivo de este trabajo es establecer un orden en el flujo interno de los materiales, por medio de la implementación de un proceso de logística interna en una compañía productora de piezas de aluminio. Para lo cual se creó un modelo que consideró variables tales como: la determinación de espacios, control de información documentada, creación de formatos de registro de trazabilidad y capacitación, el cual arrojo los siguientes resultados: mejora en los flujos internos en un $80 \%$, una correcta trazabilidad en el manejo de los materiales que redujo los tiempos en un $50 \%$, además de la incorporación de programas de plataformas administrativas. Por lo cual se determinaron los elementos adecuados que conforman la adopción de la estrategia y su medición en índices de desempeño.
\end{abstract}

Logística interna, Trazabilidad, Flujo interno

Citation: CHACÓN-OLIVARES, Maria del Carmen, RUELAS-SANTOYO, Edgar Augusto, RICO-CHAGOLLÁN, Mariana and LÓPEZ-OLIVAREZ, Jaqueline Viridiana. Internal logistics as a control and modeling tool in the processes of organizations. Journal of Microfinance Planning and Control. 2019, 5-16: 8-14

\footnotetext{
* Correspondence to Author (email: carmen.chacon@itesi.edu.mx)

$\dagger$ Researcher contributing first author.
} 


\section{Introduction}

The growth within the company has brought the arrival of new customers to the Irapuato plant, such as CONTINENTAL, MAGNA, PIERBURG, among others, this means a significant increase in production, which is why the internal flow control has been affected. However, the Production and Logistics Control area decided to create "Internal Logistics", an area that is responsible for controlling, optimizing and adapting the internal flow and rework within the company, with the main objective of streamlining the movements of the supply chain. production and also reduce downtime. Once the internal logistics department is completed, the current situation will be analyzed and conclusions will be given, as well as the main recommendations I will make for development. Thus, the project for the creation and optimization of the internal logistics area begins, which through methods such as KANBAN and analysis aims to move the work in process and control the inventories.

\section{Bibliographic review}

Experiment designs are widely used within the automotive industry to make improvements in manufacturing processes. The work of (Huamán, 2019), shows us the design of an information system for the improvement of the logistics process and warehouse control using the RUP methodology. Design methodology for cooling channel configurations in plastic injection molds used in the automotive sector.

Including (Palacin, 2019), with the implementation of a computer system for the control of fuel consumption in a heavy load transport company, this in order to improve processes and reduce the downtime that could be found. In the study carried out by (Fernández, 2019), a development of the warehouse management module is carried out to improve the management and control of materials in the electrical service in Santiago de Chuco. Hidrandina SA, supporting the two articles already mentioned.

\section{Inventory methods}

First entry, first exit (PEPS) method, last entry, first exit (UEPS) method, first in, first out (FIFO) method, last in first out (LIFO or UEPS) method, nearest date to expire (FEFO) ),

\section{What inventory?}

Raw Materials. It is the identification of all supplies of materials and raw materials to be transformed and integrated into manufacturing operations.

Products in manufacturing process. Serial production or parts of a production process also known as semi-finished or assembly product.

Finished products. Products in its composition $100 \%$, ready for packaging and packaging and subsequent placement in the market

\section{Types of inventory \\ General physical inventory}

According to Mora García (2011), Nowadays the practice of this type of exercise is very questioned by the implications and costs that it entails, however, some companies still do it. The work of counting the total of the inventories constitutes great problems and sometimes interrupts the normal operation of the company for several days, in addition this type of inventories gives an information of what there is, not about what should be.

An inventory consists of the stocks of physical products that are kept in a specific place and time. Each item other than the inventory, found somewhere, is called the stock storage unit. Inventories exist because, for reasons of physical and economic nature, it is impossible for supply and demand to coincide. (Narasimhan, 2010.)

Claudio Soriano mentions in his book of purchases and inventories that fundamentally, in a company the following types of inventories exist:

- $\quad$ Raw materials: composed of simple and elementary elements that require some degree of transformation before it can be considered as a product.

- Semi-finished products: manufactured articles that are incorporated in a larger article to constitute the final product; they are also called components. 
- Packaging: items used to package finished products before sale; It also includes items that are intended for protective packaging, both for sale and to better preserve materials during the period in which they remain in inventory.

Consumables: they are goods that are not incorporated in the finished product, but that, in one way or another, are necessary for its elaboration.

Finished products: complete articles, working and ready for sale.

Security Inventory It is the level that faces the variations in supply and demand, including delivery factors and administrative and operational procedures.

\section{Production and logistics control}

One of the pillars for the company under study is the area of production and logistics control, in it the client's requests are analyzed, in which all the quantities that he will need per week in a given period of time are detailed. Once the client's relay is received, the production at the plant is scheduled, the daily shipments that the company will have are controlled and in turn takes care of the traceability of the product, among more activities.

Internal Logistics: The main idea of this area is to control all the internal flow that the product has within the company, from when it arrives in the form of liquid aluminum or ingot, until it comes out as an acceleration body or the head of an engine and It is sent to the customer. Next, the area chart is presented, as well as the internal communication line.

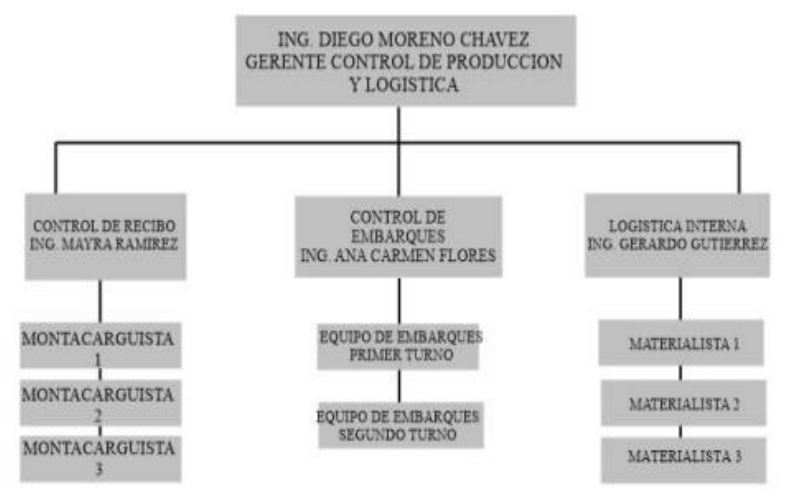

Figure 1 Organization chart of the production and logistics control area

Source: Own Elaboration

\section{Description of the activities carried out}

\section{Material handling according to the flow between the different production processes and warehouses:}

The different materialists assigned to each of the corresponding areas and shifts are responsible for requesting the material from the different production areas as "rebated or CNC" depending on their demand to produce, the person in charge of delivering the requested material asks the materialist to record in the material collection logbook, this helps to locate at what time (date and time) the lot or box that the materialist takes to his destination area was moved.

\section{Material handling in Die Casting (DC) for Shotblast:}

Keep the number of parts produced in a maximum stowage of 6 returnable boxes, the quantity of pieces that each of the boxes will contain to form batches is according to the WIP internal packing standard, see reference documents FO-LO-03- 01 WIP packing standard, each lot will contain the fifteenth color card corresponding to the day of production and the route card that indicates the pieces contained, part number, cavity, date and process through which it has passed and is about to follow; these cards are the control so that the flow is in an orderly manner respecting the PEPS system, since they are foliated consecutively.

\section{Material handling in Shotblast for Burring:}

With the same standard of flow (PEPS) and packaging, this material after having gone through the Shotblast process is accommodated in the lanes corresponding to each part number and cavity, with it the staff in deburring identifies the PEPS type flow and pull the first entries to start the deburring job.

\section{Material handling in deburring for $\mathrm{CNC}$ :}

Once the part numbers have been worked in each of the areas that make up Rebabados, they are accommodated in the WIP of the same waiting for 22 that the materialist collect the material requested by $\mathrm{CNC}$, so that the materialist can take the part numbers that are requested in cnc are necessary. 


\section{CNC online material handling for GP12:}

In this part of the process, for the $\mathrm{CNC}$ workshop it is up to you to deliver the material to make the distribution between the different machines that are working during the shift, in these different part numbers are handled specifically depending on the production schedule, for For the part numbers to arrive at the machines, it is necessary for the materialist to deliver the batches directly to each of the machines that need it, always respecting the FIFO.

\section{Handling GP12 material to finished product warehouse:}

The Inspection area or GP12 is ready to receive the material that has come out proceeding with the accommodation for inspection (last process), the material is received according to the aforementioned packing standard, it is important to say that its identification must be correct.

\section{Warehouse of Finished Product on Boarding:}

This is arranged for the protection, protection and handling of the final product, the movement towards this warehouse is made with the forklift or electric skate, the incoming product is integrated by keeping PEPS in the lanes defined for each number of part and spaces allocated to make more effective its preparation to embark (speed up the movements); which consists of strapping, site and labeling according to the packing standard, see in annexes Procedure PRLO-06 Shipments.

\section{Results obtained}

\section{Modification of the LayOut:}

Initially it was requested to redesign the current layout, in order to improve internal flows in IKD FAEZA, here the final result is presented.

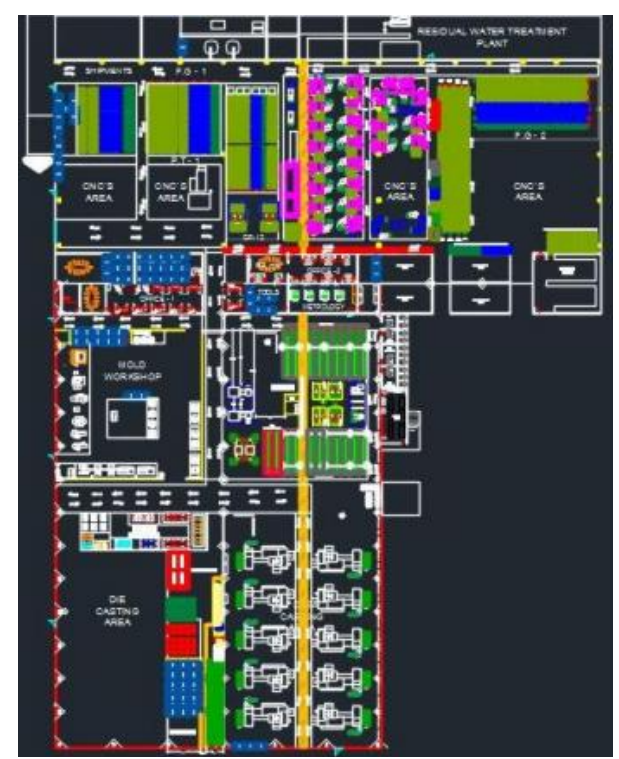

Figure 2 Redesigned Lay Out IKD FAEZA Source: Own Elaboration

\section{Creation of: "Material entry record sheet to the WIP"}

For the WIP of deburring (Warehouse In Process) it was necessary to create a record of the material entry, this in order to keep an inventory which will support us when controlling the production.

With the following data:

Delivery of rebates, No. of KANBAN, No. of parts, No. of lot and delivery time.

\section{Creation of the format: Shotblast WIP entry sheet by:}

With the need to have better control of all the materials in process that entered the shotblast WIP, the entry format called "Material entry record sheet at Shotblast WIP", here the operator fills different data which help to control the outgoing production of the Die Casting area. With the following data:

Date, part number, quantity, deliverable quantity, complete or incomplete lot and KANBAN No.

\section{Creation of the format:}

"Material movement record sheet" The burnt area sends material to the machining area (CNC), so it was necessary to keep track of the material that went from one area to another, so the following was created format in which material movements are recorded only. 
With the following data:

Data of the supervisor or leader, name and signature of the materialist, Part No. or Cavity, Supply Machine No. and KANBAN No.

Identification of lanes by part numbers on hanging signs:

In order to identify each part number that was deposited in the wip it was necessary to create hanging signs with each part number and its corresponding lane.

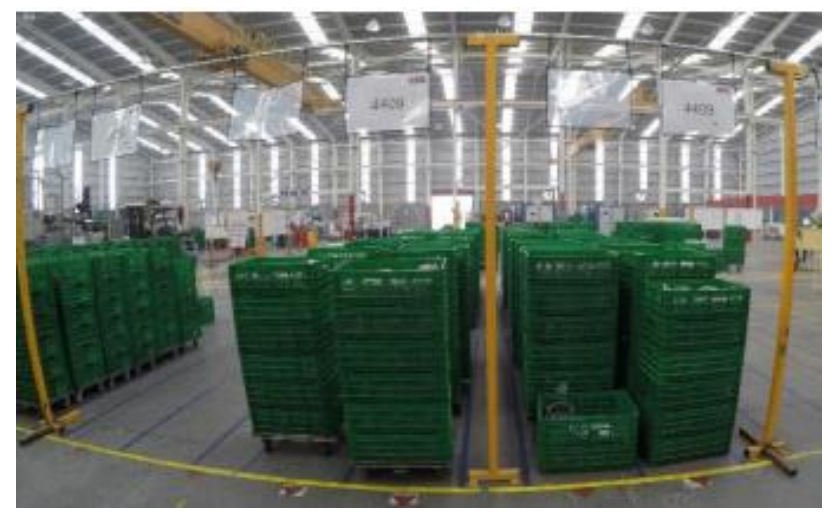

Figure 6 Evidence of delimited and identified warehouses Source: Own Elaboration

\section{Delimitation of lanes and rails of test pieces:}

It is essential to have a control in the handling of material and prevent it from mixing, so the test materials (pieces to be launched on the market) were placed in special rails, in order to avoid confusion among workers.

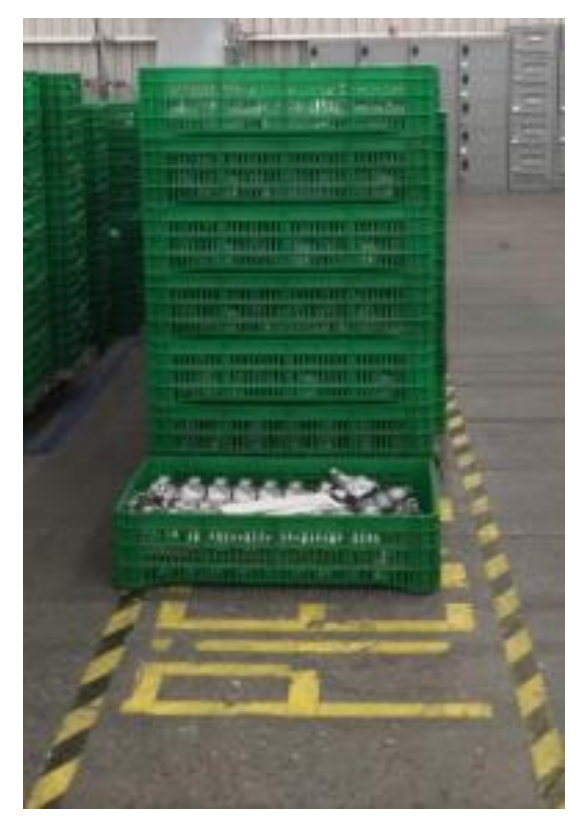

Figure 7 Evidence of special lanes Source: Own Elaboration
Place arrows along the entire floor to establish the normal workflow and rework

Normal and rework internal flow was signaled on the ground so that it was more easily identified.

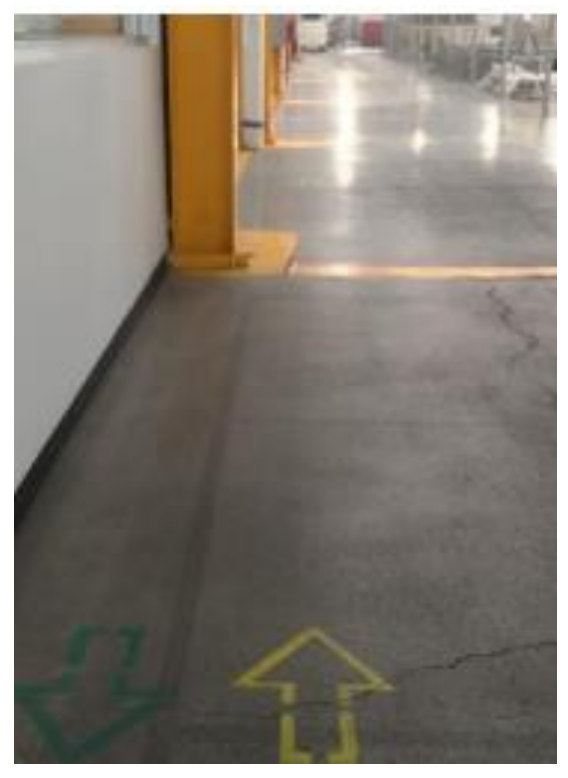

Figure 8 Signaling Evidence

Source: Own elaboration

\section{Kanban card for the CNC area created}

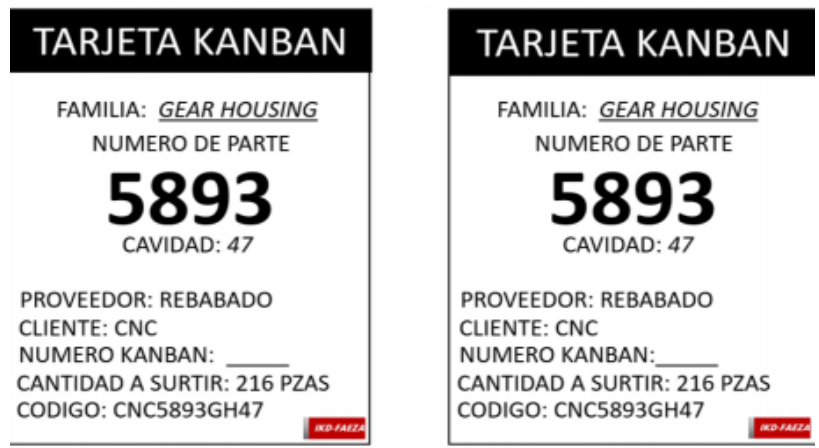

Figure 9 Kanban card created. Source: Own elaboration

\section{Andon machine system}

Banderín en maquina

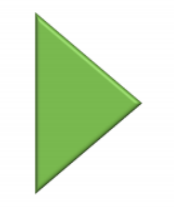

SE UTILZA CUANDO LA MAQUINA EN TURNO ESTA ABASTECIDA DE MATERIAL EN ESTE CASO LAS 2 LOTES EN ESPERA Y 1 EN PROCESO

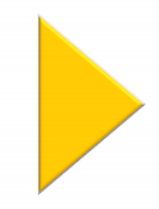

AMARILO: SE UTLIZA CUANDO LA MAQUINA EN TURNO SOLO CUENTA CON 1 LOTE EN
ESPERA Y 1 EN PROCESO

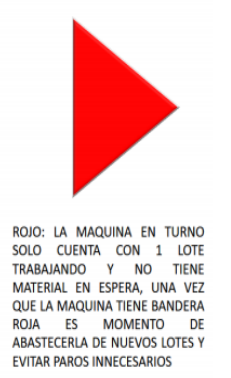

Figure 10 Screenshot, andon flag system applied in CNC Source: Own Elaboration

CHACÓN-OLIVARES, Maria del Carmen, RUELAS-SANTOYO, Edgar Augusto, RICO-CHAGOLLÁN, Mariana and LÓPEZOLIVAREZ, Jaqueline Viridiana. Internal logistics as a control and modeling tool in the processes of organizations. Journal of Microfinance Planning and Control. 2019 


\section{5 's in flow}

Periodic reviews are carried out at the plant in order to analyze the situation in which the facilities are located. This ensures that the boundaries on the floor are in good condition, the paint is still in good condition, and that the signs are clean and up to date.

\section{Traceability control}

Together with the receipt area (traceability control officers) actions were carried out in which the control of the filling of the route card is periodically reviewed, in this way we ensure that the FIFO and traceability are being controlled.

\section{FIFO control}

Special lanes were created for the reception of material in which it is verified that each lot meets the standards established by the customer.

\section{ERP system management}

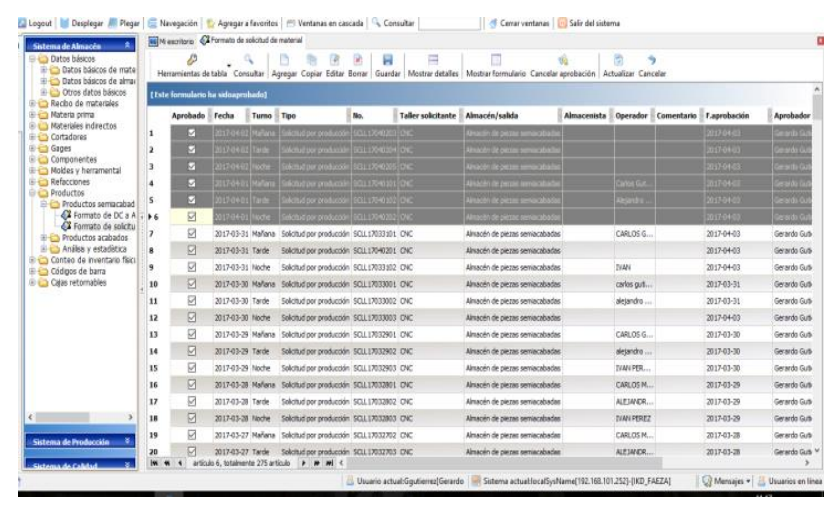

Figure 11 ERP system screenshot

Source: Own Elaboration

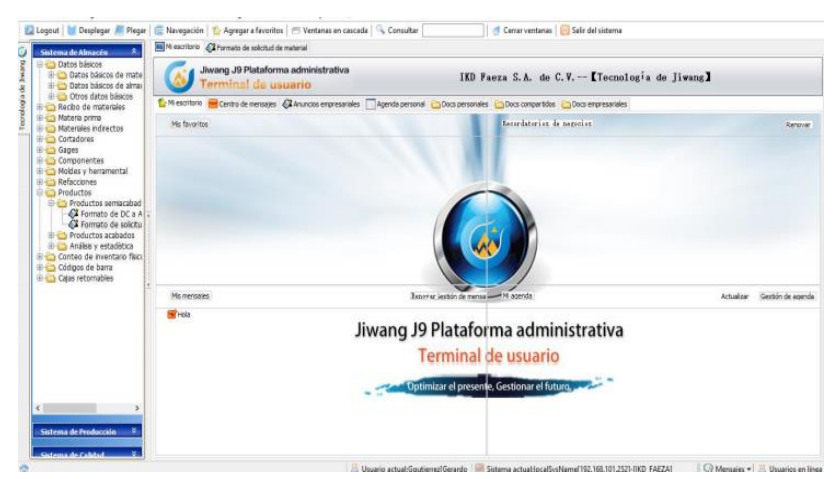

Figure 12 ERP system

Source: Own Elaboration

In creating an internal logistics model, the following elements must be considered:
Use of spaces.

- $\quad$ Short order cycles (as long as the nature of the demand is established as constant)

- $\quad$ Product availability (verification sheets)

- $\quad$ Waiting time reduction (Supplier-plant)

- Reduction of delivery time (Plantcustomer)

Access to traceability information (production)

Then according to the need and objective of the department, weighting is assigned to the aforementioned elements, so that, if your priority is the use of spaces this will have greater weight compared to the other elements.

\section{Proposed model.}

\begin{tabular}{|l|r|r|rr|r|}
\hline \multicolumn{1}{|c}{ Indicator } & \multicolumn{1}{c|}{$\begin{array}{c}\text { Weather } \\
\%\end{array}$} & \multicolumn{1}{c|}{$\begin{array}{c}\text { Cost } \\
\%\end{array}$} & Quality\% & Total \\
\hline $\begin{array}{l}\text { Space } \\
\text { utilization }\end{array}$ & & $\mathbf{4 0}$ & $\mathbf{4 0}$ & $\mathbf{2 0}$ & $\mathbf{1 0 0}$ \\
\hline
\end{tabular}

Table 1 weighting of indicators

The company sets the percentage scale according to the specifications and criteria required; In the understanding that the weighting points are established on a percentage scale to be used and these are determined in the Internal Logistics department, being this of its exclusive competence.

Suggested evaluation criteria for the space use indicator:

a) Frequency of sale according to FIFO and PEPS.

b) Production process and warehouses

c) Stowage

d) Regulations

e) Product diversity

According to Ballesteros (2008), it can include assumptions in the location of deposits, demand size, product size, promised delivery time, vehicle capacity, as indicators. It is important to mention that the indices or indicators are established based on averages and historical data. 


\section{Conclusions and Discussion}

With the creation of the Internal Logistics area, internal flows in the company under study were improved by approximately $80 \%$ since all areas of the production process were benefited, the reduction of time in the movement of material in $50 \%$ since all material transfers were expedited, the entrances and exits of the existing warehouses were controlled $100 \%$ during the three shifts, the inventories were controlled by the $100 \%$ JIWANG ERP system, everything was trained the staff so that they understood the importance of the internal logistics area as well as the internal flow. In addition to that, shipments also benefited because by making the material flow in a better way the response times of each area were optimized and this caused key areas for him to send the goods to act optimally and complete your orders.

Therefore, it can be concluded that the factors considered in the proposed model yielded favorable results in the Internal Logistics process.

\section{References}

Amaro-Martínez, D., Acevedo-Suárez, J. A., \& Amaro-Martínez, D. (2019). La integración de las finanzas al flujo logístico. Aplicación: proceso de alimentación. Ingeniería Industrial, 40(1), 97-108.

Ballesteros Riveros, (2008) Importancia de la administración logística. Scientia et technica año XIV, no 38. Universidad tecnológica de Pereira.

Ballou, R. H. (2004). Logística: Administración de la cadena de suministro. Pearson Educación.

Brian, L. S. (26 de agosto de 2007). Ingeniería industrial online. Obtenido de Ingeniería industrial online: http://www.ingenieriaindustrialonline.com/herr amientas-para-elingenieroindustrial/gesti\%C3\%B3n-dealmacenes/dise \%C3\%B10-ylayout-dealmacenes-y-centros-de-distribuci\%C3\%B3n/

Fernández, P., \& Raúl, R. (2019). Desarrollo del módulo de gestión de almacén, para mejorar la gestión y el control de materiales, en el servicio eléctrico Santiago de Chuco-Hidrandina SA; 2017.
González Gómez, C., Lizcano Rengifo, M. I., \& Villota Aldana, N. (2019). Propuesta de mejoramiento de la planeación para la logística de exportación de Aguacate Hass en la empresa Pacific Fruits International SAS.

Mora García Luis Aníbal. (2011), Gestión Logística en centro de distribución, bodegas y almacenes, Eco ediciones.

L.Narasimhan. (1996) (2a edición). Planeación de la producción y control de inventarios. México: Prentice Hall.

Huamán, H., \& Wilson, P. (2019). Diseño de un sistema de información para la mejora Del Proceso de logística y control de almacén utilizando la metodología RUP para la Municipalidad distrital de Sóndor, Provincia de Huancabamba, Departamento de Piura.

Palacin Raraz, L. G. (2019). Implementación de un sistema informático para el control de consumo de combustible en una empresa de transporte de carga pesada.

Sistemas FIFOLIFO. (21 de noviembre de 2013). Administración de la Producción. Obtenido de https://sistemasfifolifo.wordpress.com/2013/11/ 21/ventajas-ydesventajas-de-la-herramienta-2. Soriano Soriano Claudio, Compras e Inventarios, Ed. Diez de Santos. 